\title{
Potensi Daun Lamtoro (Leucaena leucocephala) sebagai Biopestisida Ulat Grayak (Spodoptera litura F.)
}

\author{
Potential of Lamtoro Leaf (Leucaena leucochepala) As Biopesticide of \\ Armyworm (Spodoptera litura F.)
}

\author{
Andriana Ela Saputri, Dwi Betty Hariyanti, Imzky Aulia Ramadhani,Wiwik Sri Harijani \\ Program Studi Agroteknologi, FakultasPertanian UPN Veteran JawaTimur, Surabaya \\ e-mail: elasaputri37@gmail.com,dwibetty03@gmail.com, imzkyaulia28@gmail.com, \\ wiwikharidjani99gmail.com
}

\begin{abstract}
ABSTRAK
Ulat Grayak (Spodoptera litura F.) adalah salah satu kendala penting dalam budidaya tanaman, karena serangan ulat ini dapat menyebabkan kerusakan yang berat dan menunurunkan hasil produksi tanaman baik secara kualitas maupun kuantitas. Pengendalian ulat grayak yang dilakukan masih menggunakan pestisida kimia yang menimbulkan berbagai dampak negative, sehingga diperlukan alternative lain yaitu biopestisida. Daun lamtoro mengandung senyawa metabolit sekunder yaitu tannin, alkaloid, saponin dan flavonoid yang dapat digunakan sebagai biopestisida untuk mengendalikan hama. Tujuan pembuatan literature review ini adalah untuk melakukan kajian terkait dengan potensi daun lamtoro (Leucaena leucocephala) sebagai biopestisida untuk pengendali hama ulat grayak. Metode yang digunakan adalah mengumpulkan literature yang relevan dari database google scholar. Berdasarkan hasil review literature yang telah dilakukan dapat diketahui bahwa daun lamtoro berpotensi dan efektif sebagai biopestisida untuk ulat grayak. Hal ini juga ditunjang dengan hasil uji beberapa penelitian yang menunjukkan bahwa konsentrasi terbaik untuk mengendalikan ulat grayak adalah antara $80-90 \%$ dengan tingkat kematian mencapai $75-90 \%$.
\end{abstract}

Kata kunci: Biopestisida, Ekstrak Daun Lamtoro, Ulat Grayak, Senyawa Metabolit Sekunder

\section{ABSTRACT}

Armyworm (Spodopteralitura F.) is one of the important problem in cultivation which can cause heavy damage and reduce crop yields both in quality and quantity. The control of armyworms that is carried out is still using chemical pesticides which cause various negative impacts, so that another alternative is needed, namely biopesticides. Lamtoro leaves contain secondary metabolite compounds, namely tannins, alkaloids, saponins and flavonoids which can be used as biopesticides to control pests. The purpose of making this literature review is to conduct studies related to the potential of lamtoro leaf as a biopesticide for armyworm control. The method used is to collect relevant literatures from the google scholar database. Based on the literature review, it was found lamtoroleaf are potential and effective as a biopesticide for armyworm. This is also supported by the result of several researches which showing that the best concentration for controlling armyworms is up to 80-90\% with a mortality rate of up to 75-90\%.

Keywords: 3Biopesticide, lamtoro leaf extract, armyworm, secondary metabolite. 


\section{PENDAHULUAN}

Serangan organisme pengganggu tanaman terutama hama merupakan salah satu kendala penting dalam budidaya tanaman. Menurut Ginandjar et al. (2018) hama adalah salah satu faktor yang dapat menurunkan hasil produksi tanaman Serangan hama dapat mengakibatkan kerusakan tanaman dan penurunan hasil baik secara kualitas maupun kuantitas. Hama yang menyerang tanaman banyak sekali macamnya, salah satunya adalah hama ulat grayak (Spodoptera litura F.). Ulat grayak menyerang dengan memakan daun pada tanaman muda hingga tinggal tulang daunnya saja (Budi et al., 2013). Ulat grayak sering menyerang tanaman kedelai, kacang hijau, jagung, dan tembakau. Kehilangan hasil akibat serangan ulat grayak mencapai $80 \%$ bahkan puso jika tidak dikendalikan. Petani dapat mengalami kerugian hingga $\mathrm{Rp} 8$ juta/Ha akibat serangan ulat grayak. Sampai saat ini pengendalian ulat grayak masih terus bergantung pada penggunaan pestisida kimia yang tentunya banyak menimbulkan dampak negative bagi lingkungan dan kesehatan manusia. Tentu dampak tersebut akan sangat berbahaya jika tidak diubah. Untuk mengatasi hal tersebut maka perlu memanfaatkan bahan yang alami yang lebih ramah lingkungan untuk mengendalikan ulat grayak.

Menurut Sarwar (2015) salah satu alternative untuk mengganti penggunaan pestisida kimia adalah dengan memanfaatkan bahan alami yang berasal dari tumbuhan sebagai pestisida nabati/biopestisida. Di alam lebih dari 1.000 spesies tumbuhan mengandung bahan biopestisida yang dapat dimanfaatkan untuk mengendalikan hama, diantaranya mengandung zat pencegah makan (antifeedant) (Krishnappa et al., 2010), mengandung zat penolak (repellent), dan pembunuh hama atau menghambat pertumbuhan serangga (Jeyasankar et al., 2014). Kelebihan pemakaian biopestisida antara lain, yaitu mudah terurai di alam, relative lebih aman terhadap musuh alami hama, dapat memperlambat laju resistensi, dan menjamin ketahanan dan keberlanjutan dalam usaha bertani. Di Indonesia banyak sekali ekstrak tumbuhan yang sudah diuji untuk mengendalikan hama, salah satunya adalah tumbuhan lamtoro, terutama bagian daun.

Menurut Windasari et al. (2012) dalam pembuatan insektisida botanis/biopestisida dapat memanfaatkan tanaman petai cina/lamtoro. Pemanfaatan tumbuhan lamtoro selama ini masih terbatas termasuk di bidang pertanian, hanya digunakan sebagai tanaman penaung bagi tanaman kopi, teh, dsb. Hasil penelitian Harmileni et al,(2019) menunjukkan bahwa konsentrasi ekstrak daun lamtoro $80 \%$ dapat membunuh ulat api dalam waktu 132,5 menit dan efektif dalam mengendalikan hama ulat api instar II. Di dalam daun lamtoro terdapat kandungan senyawa metabolit sekunder yang bekerja sebagai insektisida salah satunya adalah senyawa saponin. Saponin memiliki sifat beracun bagi hewan berdarah dingin dan dapat menghambat aktivitas makan serangga (antifeedant) sehingga dapat digunakan biopestisida. Saponin adalah surfaktan alami serupa dengan sabun yang memiliki sifat dapat menurunkan tegangan permukaan pada dinding sel larva. Adanya kandungan saponin pada daun lamtoro juga dapat memberikan efek sitotoksik dan menghambat pertumbuhan serangga pengganggu tanaman. Sehubungan dengan hal tersebut, maka dirasa perlu untuk membuat kajian literature terkait dengan potensi daun lamtoro (Leucaena leucocephala) sebagai biopestisida untuk mengendalikan hama ulat grayak dengan tujuan untuk mengetahui konsentrasi terbaik ekstrak daun lamtoro yang mampu membunuh ukat grayak dan mengetahui tingkat kematian ulat grayak. 


\section{METODE PENELITIAN}

Metode yang digunakan dalam literature review ini diawali dengan penentuan keyword untuk pencarian jurnal menggunakan Bahasa Inggris dan Bahasa Indonesia melalui database google scholar. Pencarian jurnal dimulai tanggal 11 Agustus sampai tanggal 31 Agustus 2020. Keyword dalam bahasa inggris yang digunakan adalah " lamtoro leaf extract, Spodoptera litura F. dan secondary metabolite". Sedangkan keyword dalam bahasa Indonesia adalah "ekstrak daun lamtoro, ulat grayak, senyawa metabolit sekunder".

\section{HASIL DAN PEMBAHASAN}

Daun lamtoro diduga dapat digunakan sebagai bahan biopestisida karena mengandung senyawa metabolit sekunder yaitu tanin, alkaloid, saponin dan flavonoid. Menurut Tyas et al. (2014)tumbuhan yang dapat digunakan sebagai sumber biopestisida biasanya memiliki kandungan bahan kimia senyawa metabolit primer seperti asam amino, glikosida, karbohidrta, protein, dan lemak serta memiliki kandungan senyawa metabolit sekunder alkaloid, terpenoid, flavonoid, tanin dan steroid. Kadar kandungan senyawa metabolit sekunder dalam daun lamtoro yaitu tanin 3,79 mg $100 \mathrm{~g}-1$; 5,78\% alkaloid; 5,88 \% saponin; dan 4,57\% flavonoid (Aye dan Adegun, 2013). Senyawa metabolite sekunder yang diproduksi oleh tumbuhan berguna sebagai pertanahan diri, sehingga dapat digunakan sebagai agens pelindung tanaman (Adeniyi et al., 2010). Menurut Yenie et al. (2013) senyawa tanin, saponin, alkaloid dan flavonoid diduga dapat berfungsi sebagai insektisida. Salah satu jenis insektisida yang bekerja dengan menghalangi hama memakan makanannya adalah senyawa yang bersifat antifeedant. Alkaloid, tannin, flavonoid dan saponin merupakan bahan aktif yang dapat bekerja sebagai antifeedant (Ikewuchi, 2011).

Senyawa antifeedanttidak berpengaruh terhadap kelangsungan hidup organisme lainnya, karena bekerja sangat spesifik terhadap serangga sasaran, dantidak mengganggu serangga lain. Masing-masing senyawa metabolit sekunder memiliki mekanisme yang berbeda dalam membunuh hama yang menyerang tanaman. Berdasarkan hasil penelitian Purwaningsih (2015) diketahui bahwa saponin memiliki daya bunuh terhadap telur dan larva $A$. aegypti. Saponin dapat merusak membran sel dan menganggu proses metabolisme serangga. Saponin juga diketahui memiliki efek anti jamur dan anti serangga.

Hasil penelitian Maghfiroh(2019) menunjukkan bahwa konsentrasi ekstrak gulma ajeran (B. Pilosa L.) $80 \%$ dapat membunuh ulat grayak instar III dengan mortalitas $75 \%$. Tubuh ulat grayak yang mati akibat terpapar ekstrak gulma ejeran menjadi kaku, mengerut dan berwarna kehitaman. Hal tersebut sesuai dengan hasil penelitian Syah dan Purwani (2016) bahwa kandungan saponin dalam daun belimbing wuluh dapat menyebabkan larva ulat grayak mengeras/kaku, berwarna coklat sampai kehitaman dan konsentrasi ekstrak daun belimbing wuluh yang efektif untuk membunuh larva Spodoptera litura F. yaitu antara $80-90 \%$ dengan kematian larva Spodoptera litura F. sebanyak 90\% dari total populasi dalam waktu kurang lebih 7 hari.Jumlah toksik yang terkandung dalam ekstrak daun belimbing wuluh terbilang relatif sedikit, sehingga mortalitas larva Spodoptera litura F. baru mengalami kematian jika diberi konsentrasi diatas 50\% dan untuk mencapai tingkat mortalitas yang tinggi memerlukan waktu yang lebih lama.

Hasil penelitian Muta'ali dan Purwani (2015) menunjukkan bahwa ekstrak daun beluntas (Plucea indica) berpengaruh terhadap mortalitas ulat grayak instar III. Konsentrasi 80\% dan 90\% memiliki pengaruh paling tinggi terhadap mortalitas ulat grayak yaitu mampu mematikan hampir keseluruhan larva uji yaitu 90\% dari jumlah keseluruhan larva uji. Kematian ulat grayak 
disebabkan oleh senyawa metabolit sekunder yang bersifat toksik yang terkandung dalam ekstrak daun beluntas yaitu alkanoid, flavonoid, tanin, dan saponin. Larva yang mati akibat paparan ekstrak daun beluntas menunjukkan gejala morfologi yaitu tubuh mengerut dan berwarna kecoklatan, tubuh larva lembek dan pergerakan lemah, serta tubuh mengeras dan berwarna kehitaman.

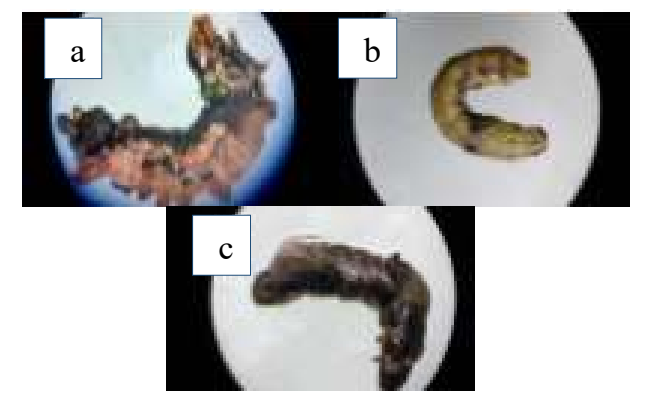

Gambar 1. Ulat Grayak yang mati karena terpapar ekstrak beluntas yang mengandung senyawa metabolit sekunder. Keterangan: a. Tubuh mengkerut dan berwarna coklat b. Tubuh lembek dan pergerakan melemah; $\mathrm{c}$. Tubuh mengeras berwarna kehitaman (gagal molting). Sumber : Muta'ali dan Purwani (2015)

Saponin menyebabkan larva mengerut dan berwarna kecoklatan (Gambar a) karena saponin dapat menghambat kerja enzim yang menyebabkan menurunnya kerja alat pencernaan. Enzim protease akan menurun akibat adanya aktivitas saponin serta dapat mengganggu penyerapan makanan (Chaieb, 2010; Kuddus et al., 2011). Masuknya saponinke dalam tubuh larva mengakibatkan terganggunya sekresi enzim pencernaan, dengan tidak adanya enzim pencernaan maka metabolisme pencernaan akan terganggu, sehingga akan mengakibatkan larva mati karena kekurangan nutrisi untuk kelangsungan hidupnya (Hasyim et al., 2019). Mekanismekerja dari senyawa saponin ialah sebagai stomach poisoning pada ulat dengan cara saponin akan menurunkan tegangan permukaan selaput mukosa traktus digertivus ulat sehingga dinding traktus digestivus menjadi korosif.Saponin juga menyebabkan iritasi lambung apabila dimakan (Utami, 2010). Adanya senyawa saponin diduga juga menyebabkan ulat grayak mengalami gagal melakukan pergantian kulit (molting) (Gambar c). Saponin dapat mengikat sterol dalam saluran makanan yang akan mengakibatkan penurunan laju sterol sebagai prekursor bagi hormone ekdison dalam hemolimfa.Dengan adanya penurunan persediaan sterol, maka proses pergantian kulit atau molting ulat grayak juga akan terganggu (Sa'diyah et al., 2013).

Selain saponin, terdapat senyawa tanin, alkaloid, dan flavonoid yang juga berperan sebagai senyawa metabolit sekunder dalam mengendalikan hama larva. Senyawa tanin menyebabkan tubuh larva lembek dan pergerakan melemah kemudian mati (Gambar b). Tanin adalah senyawa polifenol yang dapat membentuk senyawa kompleks dengan protein.Tannin mempunyai daya ikat dengan protein, karbohidrat, vitamin dan mineral serta tidak dapat dicerna oleh lambung (Ridwan, 2010). Berdasarkan hasil penelitian Hidayati et al. (2013) mekanisme kerja tanin adalah menurunkan aktivitas makan larva dengan cara menghambat aktivitas enzim reserve transcriptase dan DNA topoimerase. Apabila kerja enzim protease terhambat maka pembentukan asam amino akan menurun dengan demikian sisntesis protein tidak dapat berlangsung dan ATP tidak dapat terbentuk sehingga larva kekurangan energy dan semakin lama akan mengakibatkan kematian larva.

Berdasarkan hasil penelitian Setiawan et al. (2013) diketahui bahwa alkaloid dapat digunakan sebagai insektisida. Alkaloid yang terkandung di dalam daun atau buah segar memiliki rasa pahit di lidah, alkaloid berupa garam sehingga dapat mendegradasi membran sel 
lalu masuk ke dalam dan merusak sel. Hal tersebut sesuai dengan hasil penelitian Hapsari (2012) diketahui bahwa alkaloid akan mendegradasi membrane kulit setelah masuk ke dalam tubuh larva melalui absorbsi, selain itu alkaloid juga dapat mengganggu sistem kerja saraf larva. Senyawa alkaloid masuk kedalam tubuh larva, membuat lumpuh larvadan melisiskan sel (Cania dan Setyanigrum, 2013).

Senyawa flavonoid dapat mempengaruhi kerja sistem pernapasan larva. Hal ini sesuai dengan pendapat Ervina et al, (2014), bahwa flavonoid bekerja sebagai racun pada system pernapasan yang masuk ke dalam tubuh larva melalui siphon sehingga menyebabkan kerusakan dan larva tidak bisa bernapas dan akhirnya mati. Menurut Ayu et al, (2016) mekanisme kerja dari flavonoid yaitu ketika flavonoid termakan oleh larva atau terpapar melalui kulit larva, flavonoid akan menyebar ke seluruh jaringan dan menyerang ganglion saraf secara selektif. Hal ini akan menghambat perkembangan larva karena hormone edikson yang terlibat dalam perkembangan larva terganggu, sehingga akan menghambat pergantian kulit (molting), menyebabkan kelumpuhan dan akhirnya menyebabkan kematian.

Insektisida masuk ke dalam tubuh serangga dengan berbagai cara antara lain: sebagai racun kontak (contact poisoning) yang masuk melalui kulit atau dinding tubuh, sebagai racun perut (stomach poison) yang masuk ke dalam tubuh serangga melalui alat pencernaan, dan sebagai fumigan atau racun pernafasan yang masuk ke dalam tubuh serangga melalui sistem pernafasan (Hayne, 2014). Dengan demikian berdasarkan cara masuknya biopestisida daun lamtoro bersifat sebagai racun perut, karena sebagian besar senyawa metabolit sekunder yang terkandung di dalam daun lamtoro bersifat sebagai racun perut.

Berdasarkan beberapa hasil penelitian yang telah dilakukan terkait pengendalian hama ulat grayak menggunakan jenis tanaman yang mengandung senyawa metabolit sekunder dapat diduga bahwa daun lamtoro memiliki potensi sebagai biopestisida untuk hama ulat grayak. Hal tersebut disebabkan daun lamtoro juga mengandung senyawa metabolit sekunder seperti tumbuhan lain. Dari beberapa literature tersebut diketahui konsentrasi terbaik yang efektif untuk mengendalikan larva termasuk ulat grayak instar II dan III adalah hingga 80-90\% dengan tingkat kematian mencapai $75-90 \%$. Tingkat mortalitas ulat grayak selain bergantung pada tingkat konsentrasi juga ditentukan oleh besar kecilnya kandungan senyawa metabolit yang terkandung dalam bahan yang digunakan sebagai biopestisida. Biopestisida daun lamtoro juga diduga bersifat sebagai racun perut karena sebagian besar jenis senyawa metabolit sekunder yang terkandung dalam daun lamtoro bekerja sebagai racun perut. Instar II dan III dipilih sebagai bahan uji karena menurut hasil penelitian Musyahadah et al. (2016) beberapa insektisida lebih efektif ketika diaplikasikan pada ulat grayak instar II dan III dengan mortalitas $90 \%$ dan $70 \%$ untuk instar III dan IV, sehingga semakin tua umur larva maka mortalitas cenderung semakin menurun. Tingkat konsentrasi biopestisida berbanding lurus dengan tingkat kematian ulat grayak. Semakin tinggi konsentrasi yang diberikan maka semakin tinggi pula tingkat kematian ulat grayak (Nihayah et al., 2016).

\section{KESIMPULAN}

Berdasarkan hasil review literature yang telah dilakukan, maka dapat disimpulkan bahwa daun lamtoro diduga berpotensi dan efektif sebagai biopestisida untuk hama ulat grayak dengan konsentrasi terbaik antara $80-90 \%$ dengan tingkat kematian ulat grayakmencapai $75-90 \%$. 


\section{DAFTAR PUSTAKA}

Adeniyi, S. A., C. L. Orjiekwe, J. E. Ehiagbonare, dan B. D. Arimah, 2010. Preliminary phytochemical analysis and insecticidal activity of ethanolic extracts of four tropical plants (Vernonia amygdalina, Sida acuta, Ocimum gratissimum, and Telfaria occidentalis) against beans weevil (Acanthscelides obtectus). International Journal of the Physical Sciences. 5 (6). pp. 753-762.

Aye P. A dan M. K. Adegun. 2013. Chemical composition and some functional properties of moringa, leucaena and gliricidia leaf meals. Agriculture and Biology Journal of North America. 4(1): pp. 71-77.

Budi, A.S., A. Afandhi, dan R. D. Puspitarini. 2013. Patogenisitas jamur entomopatogen Beauveria bassianaBalsamo (Deutromycetes : Moniliales) pada larva Spodoptera litura Fabricius (Lepidoptera : Noctuidae). Jurnal HPT. 1(1): 79-83.

Cania, E. dan E. Setyaningrum. 2013. Uji efektivitas larvasida ekstrak daun legundi (Vitex trifolia) terhadap larva aedes aegypti. Medical Journal of Lampung University. 2(4): 5260.

Chaieb, I. 2010. Saponins as insecticides: a review. Tunisian Journal of Plant Protection. 39-50.

Ervina, N., L. Pratiwi, dan D. Natalia. 2014. Uji Aktivitas Ekstrak Etanol Daun Singkong (Manihot utilissima Pohl.) Sebagai Larvasida Aedes aegypti. Jurnal Mahasiswa PSPD FK Universitas Tanjungpur. 1(1):1-12.

Ginandjar, S., Dikayani, dan F. S. Nurhakim. 2018. Response Kailan Plants (Brassica Oleraceae L.) To The Immersion Plant. Asian Journal of Agriculture and RuralDevelopment. 8 (2): 195-203.

Hapsari, A.O. 2012. Efektifitas Ekstrak Buah Belimbing Wuluh (Averrhoa bilimbi 1.) terhadap Mortalitas Larva Nyamuk Aedes aegypti.Skripsi. Riau: Jurusan Pendidikan Biologi Universitas Riau.

Harmileni, K. Wijaya., B. Pratomo, S. Hardianingsih., dan E. Fachrial. 2019. Uji Efektivitas Daun Lamtoro (Leucaena Leucocephala Lam.) Sebagai Biopestisida Dalam Pengendalian Hama Ulat Api (Setothesea asigna v.Eecke). Seminar Nasional Teknologi Komputer \& Sains (SAINTEKS). Januari 2019. Hal: 177-181.

Hasyim, A., W. Setiawati, L. Lukman, dan L. S. Marhaeni. 2019. Evaluasi Konsentrasi Lethal dan Waktu Lethal Insektisida Botani Terhadap Ulat Bawang (Spodoptera exigua) di Laboratorium. J. Hort. 29(1): 69-80.

Hayne, K. F. 2014. Sublethal effect of neurotoxic insecticides on insect behavior. Annual Review of Entomologi. 33: 149-168. 
Hidayati, N. N., Yuliani, dan N. Kuswani. 2013. Pengaruh ekstrak daun suren dan daun mahoni terhadap mortalitas dan aktivitas makan ulat daun (Plutella xylostella) pada tanaman kubis. Jurnal LenteraBio. 2(1): 95-99.

Jeyasankar, A, N. Raja, dan S. Ignacimuthu. 2011. Insecticidal compound isolated from Syzygium lineare Wall. (Myrtaceae) against Spodoptera litura (Lepidoptera: Noctuidae), Saudi Journal of Biological Sciences. 18. pp. 329-332.

Kakaid. 2019. 15 Manfaat Daun Lamtoro dan Kandungan Daun Lamtoro. URL: https://bungabunga.co.id/daun-lamtoro/. Diakses tanggal September 2019

Kardinan A. 2011. Penggunaan insektisida nabati sebagai kearifan lokal dalam pengendalian hama tanaman menuju sistem pertanian organik. Bul. Littro. 23(2). 148-152.

Krishnappa, K, Anandan,A, Mathivanan,T, Elumalai, K dan Govindarajan, M. 2010. Antifeedant activity of volatile oil of Tagetes patula against armyworm, Spodoptera litura (Fab.) (Lepidoptera: Noctuidae).International Journal of Current Research. 4. pp. 109112.

Kuddus, M. R., F. Rumi, F dan Masud, M. M. 2011. Phytochemical screening and antioxidant activity Studies of Cerbera odollam Gaetrn. Int. J. Pharm. Bio. Sci. 2 (1). pp. 413-418.

Maghfiroh, D. 2019. Pengaruh ekstrak gulma ajeran (Bidens pilosa L.) terhadap mortalitas dan perkembangan larva ulat grayak (Spodoptera litura F.). Skripsi. Fakultas Sains dan Teknologi. UIN Maulaa Malik Ibrahim. Malang.

Musyahadah, N., Hariani, N., dan Hendra, M. 2015. Uji Efektivitas Ekstrak Daun Tigaron Terhadap Mortalitas Ulat Grayak (Spodoptera litura F.) (Lepidoptera:Noctuidae) di laboratorium. Prosiding Seminar Sains dan Teknologi Fmipa Unmul. 1(1): 1-7.

Muta'ali, R., dan K. I. Purwani. 2015. Pengaruh ekstrak daun beluntas (Pluchea indica) terhadap mortalitas dan perkembangan larva Spodoptera litura F.Jurnal Sains dan Seni ITS. 4(2): 55-58.

Nihayah A., A. Ginanjar dan T. Sopyan. 2016. Pengaruh Ekstrak Etanol Cabai Merah (Capsicum annum L.) Terhadap Mortalitas Hama ULat Grayak (Spodoptera litura F.). Jurnal Pendidikan Biologi (Bioed). 4(1): 27-31.

Purwaningsih, N. V., M. P. Kardiwinata, dan N. W. A. Utami. 2015. Daya bunuh ekstrak daun srikaya (A. sqyamosa L.) terhadap telur dan larva A. aegypti. Cakra Kimia (Indonesian EJournal of Applied Chemistry). 3(2): 96-103.

Putra, I. P. 2017. Aktivitas inhibisi fraksi ekstrak daun beluntas (Pluchea indica(L) Less.) terhadap target Obat Antimalaria Plasmodium falciparum malate quinone oxidoreductase (pfmqo). Skripsi. Fakultas Kedokteran dan Ilmu Kesehatan UIN Syarif Hidayatullah. Jakarta. 
Ridwan, Y. 2010. Efektivitas Anticestoda Ekstrak Daun Miana (Coleus Numel Benth) Terhadap Cacing Hymenolepis microstoma pada Mencit. Media Peternakan. 33 (1):6-11.

Sa'diyah, N. A., K. I Purwani., Wijayawati L. 2013. Pengaruh Ekstrak Daun Bintaro (Carbera odollam) terhadap Perkembangan Ulat Grayak (Spodoptera litura F.). Jurnal Sains dan Seni PomITS. 2(2): 111-15.

Setiawan, T., S. Aminah, dan M. R. Jura. 2013. Analisis senyawa alkaloid daun tanaman johar (Cassia siamea Lmk.) yang berpotensi sebagai insektisida pada nyamuk. J. Akademika $\operatorname{Kim}$ 2(3): 145-152.

Sinarso, D. S. 2019. Serangan Ulat Baru Meluas, Petani Jagung Ganti Komoditas. Agrina. (https://www.agrina-online.com/detail). Diakses pada 9 Oktober 2019.

Syah, B. W., dan K. I. Purwani, 2016. Pengaruh Ekstrak Daun Belimbing Wuluh (Averrhoa bilimbi) terhadap Mortalitas dan Perkembangan Larva Spodoptera litura. Jurnal Sains dan Seni ITS. 5(2): 23-28.

Utami, S. 2010. Aktifitas Insektisida Bintaro (Cerbera odollam Gaertn) Terhadap Hama Eurema sp. pada Skala Laboratorium. Jurnal Penelitian Hutan Tanaman. 7:211-220.

Windasari N., Priyono B., dan Martuti N. 2012. Toksisitas Ekstrak Biji Srikaya dan Pengaruhnya terhadap Viabilitas Rayap Kayu Kering. Unnes Journal of Life Science. 1(1): 1-7.

Yenie, E., S. Elystia, A. Kalvin, dan M. Irfhan. 2013. Pembuatan Pestisida Organik Menggunakan Metode Ekstraksi dari Sampah Daun Pepaya dan Umbi Bawang Putih. Jurnal Teknik Lingkungan. 10. 46-59. 